\title{
Assessing the Utilization of Building Information Modelling Software for Project Planning in Construction Industries in Ondo State
}

\author{
Deborah Vincent ${ }^{1}$, Samson Ojo ${ }^{2}$, Hyginus Omeje ${ }^{3}$ \\ ${ }^{1}$ Department of Industrial Technical Education, University of Nigeria, Nsukka,Nigeria \\ ${ }^{2}$ Department of Industrial Technical Education, University of Nigeria, Nsukka. abayomi.ojo@unn.edu.ng \\ ${ }^{3}$ Department of Industrial Technical Education, University of Nigeria, Nsukka.hyginus.omeje@unn.edu.ng
}

\begin{tabular}{|c|c|}
\hline Artic & Abstract \\
\hline $\begin{array}{l}\text { Article history: } \\
\text { Received: } 02 \text { September } 2020 \\
\text { Revised: } 06 \text { November } 2020 \\
\text { Accepted: } 07 \text { November } 2020\end{array}$ & $\begin{array}{l}\text { Purpose: The purpose of this study was to assess the utilization of building } \\
\text { information modelling (BIM) software for project planning in construction } \\
\text { industries in Ondo-State. } \\
\text { Approach/Methodology/Design: Three research questions guided the study. A }\end{array}$ \\
\hline $\begin{array}{l}\text { Keywords: } \\
\text { Building Information } \\
\text { Modelling (BIM) Software, } \\
\text { Utilization, } \\
\text { Project Planning, } \\
\text { Construction Industries. }\end{array}$ & $\begin{array}{l}\text { survey research design was adopted for the study. The population for the } \\
\text { study comprised of } 31 \text { construction industries with } 126 \text { Contractors and } \\
\text { Building consultants in construction industries in Ondo-State, Nigeria. A } \\
\text { structured questionnaire consisting of } 41 \text { items developed by the ERASMUS + } \\
\text { programme was used for data collection. Two experts from the Department of } \\
\text { Industrial Technical Education (Building/Woodwork), University of Nigeria, } \\
\text { Nsukka, and one expert from Bablor Construction Company, Akure South, } \\
\text { Ondo-State validated the instrument. The reliability co-efficient of the }\end{array}$ \\
\hline JEL: O21, O & $\begin{array}{l}\text { instrument was } 0.86 \text {. Data collected were analyzed using mean to answer the } \\
\text { research questions, while t-test was used to answer the hypotheses. }\end{array}$ \\
\hline Paper Type : & $\begin{array}{l}\text { Findings: It was found that the extent to which building information } \\
\text { modelling (BIM) software are utilized are still very low. The study therefore, }\end{array}$ \\
\hline Resea & $\begin{array}{l}\text { recommend that education and training programmes on BIM software uses } \\
\text { should be organized for construction industries, BIM should be made }\end{array}$ \\
\hline Corre & $\begin{array}{l}\text { compulsory for all personnel involved in construction process and a standard } \\
\text { contract document should be made available by the government/professional }\end{array}$ \\
\hline Deborah Vincent & $\begin{array}{l}\text { bodies for all building constructors to ensure the usability of BIM for } \\
\text { construction project to enhance the construction design, process, analyze and }\end{array}$ \\
\hline Email: & $\begin{array}{l}\text { resolve potential hazards and ensure that the building project is completed } \\
\text { timely. }\end{array}$ \\
\hline debbyv8@gmail.c & $\begin{array}{l}\text { Practical Implications: The study revealed the benefit of BIM software } \\
\text { application for project planning Hence, the importance of BIM software } \\
\text { cannot be overemphasized in achieving high building quality, innovative } \\
\text { virtual design and project management in the modern world. } \\
\text { Originality/value: This paper shows that Building information modelling } \\
\text { software is an innovative way to practically design and manage project plan. } \\
\text { BIM adoption is needed to enhance building performance and operation. }\end{array}$ \\
\hline
\end{tabular}

\section{Introduction}

Building Information Modelling (BIM) Software represents the digital formation. Erin (2016) described Building Information Modelling (BIM) Software as a software used by designers to create a building project with integrated information in a format that models both the structure and the entire timeline of a project from commencement to eventual demolition. The use of Building Information Modelling (BIM) Software gives architecture, engineering and construction experts the insight and tools to efficiently plan, design, construct and manage buildings and infrastructure in the construction industry. 
Milyutina (2018) affirmed that Building Information Modelling software is integrated into all stages of building production and sustenance such as data gathering, design, construction, machineries, building operations, repairs and demolition. The construction industry has continued to evolve with time to achieve efficient and effective service delivery

Boukaraa and Naamane (2015) reported that over the past few years, the number of Building Information Modelling software technology users and buildings designed using the technology has grown drastically and this trend is expected to continue. However, studies have shown that Ondo-State construction industries are yet to fully adopt the Building Information Modelling software system for building construction project planning. The application of BIM software in building construction project planning improves project planning, visualization, management, workflow and partnership with all building personnel. Nevertheless, in Ondo-state there may be low availability of BIM technology tools and technologies and poor standardization of BIM process in the construction industry that are required to increase productivity, efficiency, quality and sustainability of building construction process. In addition, building construction professionals do not have the required skills and competency to operationalize BIM technology for construction processes.BIM being a rising technology in Nigeria construction industry is expected to deliver many benefits to the industry.

Based on this premise, this paper attempts to examine the extent of utilization of BIM by client and building professionals in Ondo-state building construction industries. The general purpose of this study is to assess the extent of the utilization of Building Information Modelling (BIM) Software for Project Planning in Construction industries in Ondo-State, Nigeria. Specifically, the study also sought to identify the benefits of Building Information Modelling (BIM) Software applications for Project Planning in Construction industries in Ondo-State and to identify the challenges faced in Building Information Modelling (BIM) Software applications for Project Planning in Construction industries in Ondo-State. Moreover, the study examines the extent to which Building Information Modelling (BIM) Software applications are used for Project Planning in Construction industries in Ondo-State.

\section{Methodology and Procedures}

\section{Participants}

A descriptive survey design was adopted for this study. The study was carried out in Ondo- State in 2019. The population of the study consisted of 126 Contractors and Building consultants in construction industries in Ondo-State, Nigeria. The questionnaire was administered among a randomly selected sample group, comprising of practicing professionals in the construction industries in the study area. These professionals include contractors (main and sub), Building Consultants (architects, builders, quantity surveyors, project managers, structural engineers, electrical engineer, and mechanical engineer). 
Table 1: Participant characteristics

\begin{tabular}{llll}
\hline S/No & Professionals & $\%$ & $\mathrm{~N}$ \\
\hline 1 & Contractors & 17.4 & 22 \\
2 & Architects & 12.6 & 16 \\
3 & Builders & 15.8 & 20 \\
4 & Quantity Surveyors & 4.7 & 06 \\
5 & Project Managers & 19.5 & 24 \\
6 & Structural Engineers & 14.2 & 18 \\
7 & Electrical Engineer & 9.5 & 12 \\
8 & Mechanical Engineer & 6.3 & 08 \\
& Total & 100 & 126 \\
\hline
\end{tabular}

\section{Instrument for Data Collection}

The instrument used for the study was a structured questionnaire with four sections A, B, C and D. Section A elicited demographic information of the respondents while Section B, C and D had 41 item statements that sought information to answer the research questions. The responses were designed based on 4-point scale which ranges from 4 to 1 . The responses to research question 1 and 2 comprised of the following -Strongly Agreed $(S A)=4$, Agreed $(A)=3$, Disagreed $(D)=2$ and Strongly Disagreed $(S D)=1$; while Research question 3 had responses of: Highly Utilized $(H U)=4$, Utilized $(U)=3$, Not Utilized $(N U)=2$ and Highly Not Utilized $(H N U)=1$; The questionnaire was face validated by three experts; two experts from the Department of Industrial Technical Education (Building/Woodwork), University of Nigeria, Nsukka, and one expert from Bablor Construction Company, Akure South, Ondo-State.

\section{Method of Data Analysis}

The data collected from the study was analyzed using mean for answering the research questions and t-test for testing the hypotheses at probability level of 0.05 and 95 degree of freedom (df). Any item with a mean value of 2.50 and above was regarded as Agreed upon/utilized while any item with a mean below 2.50 was regarded as Disagreed/Not utilized. Data analyses were carried out using SPSS 22.0 as statistical packages. The statistical tools we employed are mean, Cronbach's alpha, and Independent samples t-test. The SPSS was used to determine the mean and Independent samples t-test. For the test of significance, the probability $(p)$ value was used in comparison with the alpha value of .05 , and at other relevant levels.

\section{Results and Discussion}

The data for answering Research question 2 are presented in Table 2.

Table 2: Mean and t-test Analysis of the Responses of Contractors and Building Consultants on the benefits of Building Information Modelling (BIM) Software applications for Project Planning in Construction industries in Ondo-State.

\begin{tabular}{llllllll}
\hline S/N & Item Statements & $\mathrm{X}$ & Decision & $\mathrm{t}-\mathrm{cal}$ & $\mathrm{Df}$ & Sig. & $\mathrm{H}_{0}$ \\
\hline 1 & $\begin{array}{l}\text { Using BIM will improve productivity } \\
\text { of on-site work }\end{array}$ & 3.28 & Agreed & .55 & 40 & .58 & $\mathrm{NS}$
\end{tabular}


2 Using BIM will enhance construction planning

3 Using BIM will enable planning and visualizing the entire project during preconstruction

$4 \quad$ Using BIM will communicate information to all stakeholders involved in the building project

5 Using BIM will reduce cost and mitigation risk

6 Using BIM will improve the building quality

7 Using BIM will coordinate and detect clash

8 Using BIM will help in project control

9 Using BIM will save time in the construction process

10 Using BIM will detect potential hazard in the construction process

11 Using BIM will hasten the project development

12 Using BIM will enhance safety management

13 Using BIM will help in project management

14 Using BIM will check the logistics and functioning of building construction project

$\begin{array}{llllll}3.11 & \text { Agreed } & .91 & 40 & .37 & \text { NS } \\ 3.14 & \text { Agreed } & & 40 & .38 & \text { NS }\end{array}$

$3.16 \quad$ Agreed

$40 \quad .91 \quad$ NS

3.19 Agreed

$\begin{array}{lll}40 & .48 \quad \mathrm{NS}\end{array}$

$3.23 \quad$ Agreed

.70

$40 \quad .30$

NS

3.19 Agreed

1.05

$40 \quad .48$

NS

3.14 Agreed

$3.21 \quad$ Agreed

.70

1.57

$40 \quad .14$

NS

1.21

$40 \quad .23 \quad \mathrm{NS}$

$3.14 \quad$ Agreed

$1.17 \quad 40 \quad .26 \quad$ NS

3.09 Agreed

$\begin{array}{llll}.67 & 40 \quad .50 & \text { NS }\end{array}$

3.23 Agreed

.49

40

.62

NS

3.19 Agreed

40

.62

NS

3.07 Agreed

$40 \quad .28$

NS

1.08

15 Using BIM will enhance safety control 3.26 Agreed

.38

$40 \quad .70 \quad \mathrm{NS}$

Note $\boldsymbol{X}=$ Grand Mean $; \boldsymbol{T}$-cal $=$ T-Calculated, Strongly Agreed $(S A)=4$, Agreed $(A)=3$, Disagreed $(D)=2$ and Strongly Disagreed $(S D)=1 ; \boldsymbol{N S}=$ Not Significant $; \boldsymbol{H}_{\boldsymbol{0}}=$ Null Hypothesis $; \boldsymbol{d} \boldsymbol{f}=$ Degree of freedom

The data for answering Research question 3 are presented in Table 3

Table 3: Mean and t-test Analysis of the Responses of the challenges faced in Building Information Modelling (BIM) software applications for Project Planning in Construction industries in Ondo-State

\begin{tabular}{|c|c|c|c|c|c|c|c|}
\hline $\mathrm{S} / \mathrm{N}$ & Item Statements & $\mathrm{X}$ & Decision & $\mathrm{t}$-cal & Df & Sig. & $\mathrm{H}_{0}$ \\
\hline 1 & Client unawareness of BIM & 3.16 & Agreed & .70 & 40 & .49 & NS \\
\hline 2 & High cost of training for Users & 2.83 & Agreed & 1.39 & 40 & .17 & NS \\
\hline 3 & Low availability of BIM technology & 3.07 & Agreed & .47 & 40 & .64 & NS \\
\hline 4 & Poor government support & 2.69 & Agreed & .26 & 40 & .79 & NS \\
\hline 5 & $\begin{array}{l}\text { Poor standardization of BIM process } \\
\text { in the construction industry }\end{array}$ & 2.88 & Agreed & .17 & 40 & .86 & NS \\
\hline 6 & $\begin{array}{l}\text { Industries/Building consultant's } \\
\text { resistance to trends }\end{array}$ & 3.04 & Agreed & .93 & 40 & .35 & NS \\
\hline 7 & $\begin{array}{l}\text { Poor BIM structure in the construction } \\
\text { industry }\end{array}$ & 2.85 & Agreed & .79 & 40 & .44 & NS \\
\hline 8 & $\begin{array}{l}\text { Poor knowledge of BIM by } \\
\text { professionals }\end{array}$ & 2.95 & Agreed & .86 & 40 & 40 & NS \\
\hline 9 & $\begin{array}{l}\text { No requirement of BIM technologies } \\
\text { for typical projects (small projects) }\end{array}$ & 2.98 & Agreed & 1.28 & 40 & .21 & NS \\
\hline
\end{tabular}


10 Computer illiterate

2.25 Agreed

.64

40

$.53 \quad \mathrm{NS}$

Note $\boldsymbol{X}=$ Grand Mean; $\boldsymbol{T}$-cal $=$ T-Calculated, Strongly Agreed $(S A)=4$, Agreed $(A)=3$, Disagreed $(D)=2$ and Strongly Disagreed $(S D)=1 ; \boldsymbol{N S}=$ Not Significant $; \boldsymbol{H}_{\boldsymbol{0}}=$ Null Hypothesis $; \boldsymbol{d} \boldsymbol{f}=$ Degree of freedom

The data for answering Research question 4 are presented in Table 4.

Table 4: Mean and t-test Analysis of the Responses of the extent to which Building Information Modelling (BIM) software are utilized for Project Planning in Construction industries in OndoState

\begin{tabular}{|c|c|c|c|c|c|c|c|}
\hline $\mathrm{S} / \mathrm{N}$ & Item Statements & $\mathrm{X}$ & Decision & t-cal & Df & Sig. & $\mathrm{H}_{0}$ \\
\hline 1 & $\begin{array}{l}\text { I use BIM for pre-project planning } \\
\text { services }\end{array}$ & 2.52 & $\mathrm{U}$ & 1.25 & 40 & .22 & NS \\
\hline 2 & I use BIM for Project Management & 2.95 & $\mathrm{U}$ & 1.24 & 40 & .22 & NS \\
\hline 3 & I use BIM for Project control & 2.38 & NU & .13 & 40 & .89 & NS \\
\hline 4 & $\begin{array}{l}\text { I use BIM to reduce cost and } \\
\text { mitigation risk }\end{array}$ & 2.47 & NU & .86 & 40 & .40 & NS \\
\hline 5 & $\begin{array}{l}\text { I use BIM to detect clash in the } \\
\text { construction process }\end{array}$ & 2.71 & $\mathrm{U}$ & .61 & 40 & .54 & NS \\
\hline \multirow[t]{2}{*}{6} & I use BIM to communicate & 2.52 & $\mathrm{U}$ & & 40 & .61 & NS \\
\hline & $\begin{array}{l}\text { information to all the stakeholders } \\
\text { involved in the construction } \\
\text { process }\end{array}$ & & & .51 & & & \\
\hline 7 & $\begin{array}{l}\text { I use BIM to improve the building } \\
\text { quality }\end{array}$ & 2.40 & NU & .31 & 40 & .75 & NS \\
\hline 8 & $\begin{array}{l}\text { I use BIM in safety management } \\
\text { and control }\end{array}$ & 2.80 & $\mathrm{U}$ & .05 & 40 & .95 & NS \\
\hline 9 & $\begin{array}{l}\text { I use BIM to save time in the } \\
\text { construction process }\end{array}$ & 2.57 & $\mathrm{U}$ & .19 & 40 & .84 & NS \\
\hline 10 & $\begin{array}{l}\text { I use BIM to detect potential hazard } \\
\text { in the construction process }\end{array}$ & 2.38 & NU & .12 & 40 & .89 & NS \\
\hline 11 & $\begin{array}{l}\text { I use BIM to hasten the project } \\
\text { development }\end{array}$ & 2.42 & NU & .49 & 40 & .62 & NS \\
\hline 12 & $\begin{array}{l}\text { I use BIM to check logistics and } \\
\text { functioning of building } \\
\text { construction project }\end{array}$ & 2.47 & NU & 1.55 & 40 & .14 & NS \\
\hline 13 & $\begin{array}{l}\text { I use BIM to plan and visualize the } \\
\text { entire project during } \\
\text { preconstruction }\end{array}$ & 2.57 & $\mathrm{U}$ & .82 & 40 & .42 & NS \\
\hline 14 & $\begin{array}{l}\text { I use BIM for construction } \\
\text { sequencing }\end{array}$ & 2.54 & $\mathrm{U}$ & .67 & 40 & .50 & NS \\
\hline 15 & I use BIM for forensic analysis & 2.66 & $\mathrm{U}$ & .23 & 40 & .81 & NS \\
\hline 16 & $\begin{array}{l}\text { I use BIM for facilities } \\
\text { management }\end{array}$ & 2.19 & NU & .71 & 40 & .48 & NS \\
\hline 17 & $\begin{array}{l}\text { I use BIM for conceptual design } \\
\text { support }\end{array}$ & 2.30 & NU & .40 & 40 & .68 & NS \\
\hline
\end{tabular}

Note $\boldsymbol{X}=$ Grand Mean; $\boldsymbol{T}$-cal $=$ T-Calculated, Highly Utilized $(H U)=4$, Utilized $(U)=3$, Not Utilized $(N U)=2$ and Highly Not Utilized $(H N U)=1 ; N S=$ Not Significant $; \boldsymbol{H}_{0}=$ Null Hypothesis; $\boldsymbol{d} \boldsymbol{f}=$ Degree of freedom 


\section{Discussion of Results}

The findings of the study showed that BIM software is utilized for project planning in construction industries in Ondo-state but the usage is very limited. This is in line with Azhar et al. (2008) in which they stated that BIM software adoption has been much slower than anticipated. It also showed that BIM software is not utilized for project control, cost and mitigation risk reduction, improvement of building quality, detection of potential hazard in construction process, for hastening project development, checking logistics and functioning of building construction project, facilities management and conceptual design support for project planning in construction industries in Ondo-state which simulate the operation of a construction project. Hence, it is recommended the government and professional bodies to make BIM software application compulsory for project planning.

The findings of the study also revealed that the challenges faced in BIM software application for project planning in Ondo-State are client's unawareness of BIM software, high cost of training, low availability of BIM technology and poor standardization of BIM process in the construction industry. This is in line with the findings of Brewer et al. (2012) as they stated that technical challenges, skills and training challenges, legal and procedural challenges, cost challenges, are the challenges for using BIM on construction.

Finally, the study revealed that BIM application is beneficial for project planning. Hence, the importance of BIM software cannot be overemphasized in achieving high building quality, innovative virtual design and project management in the modern world. This is in line with Qian, (2012) who stated that BIM enhanced project collaboration and control among stakeholders, improved productivity, better project quality and performance, faster project delivery, reduced wastages, reduced construction costs, new revenue and business opportunities.

\section{Conclusion and Suggestion}

Based on the findings of the study, it was revealed that the adoption of Building information modelling software technology is low in Ondo-State. This paper shows that Building Information Modelling software is an innovative way to practically design and manage project plan. BIM adoption is needed to enhance building performance and operation. This paper shows that BIM software can be used for project planning, design, preconstruction and construction phases in building construction process. These capabilities have empowered BIM to play a significant role in project planning and management. Therefore, BIM is imperative to stimulate construction project planning and the construction process to analyze and resolve issues and ensure that the project is completed timely.

\section{Recommendations}

Based on the findings of the study, the following recommendations were made:

- Education and training programme on BIM software should be organized to sensitize all building teams on the importance of BIM software technology. 
- Appropriate BIM software technology and infrastructure should be provided by the construction project managers.

- Building Information Modelling software technology should be made compulsory by the government and professional bodies for all building contractors or personnel involved in construction process.

- A standard contract document should be integrated to building regulations by the government or professional bodies for project managers to ensure the usability of BIM for construction project.

\section{Conflict of interests}

The authors declare no conflict of interest.

\section{Funding}

The study has no financial assistance/ funds to recognise.

\section{References}

Azhar, S., Hein, M and Sketo, B. (2008). Building Information Modeling: Benefits, Risks and Challenges. PROC 44th Associated Schools of Construction National Conference, Auburn, AL.

Boukaraa, A \&Naamane, A. (2015) A Brief Introduction to Building Information Modeling (BIM) and its interoperability with TRNSYS, Journal of Renewable Energy and Sustainable Development (RESD), Retrieved online from http://apc.aast.edu, Pp 126-130.

Brewer, G., Gajendran, T., and Goff, R. (2012). Building Information Modelling (BIM): An Introduction and International Perspectives,Tasmanian Building and Construction Industry Training Board Report, The University of Newcastle.

Erin, A. (2012). Building Information Modelling. Retrieved online from https://www.engineering.com/BIM/ArticleID/11436/BIM-101-What-is-BuildingInformation-Modeling.aspx.

Fahad,A. (2019). Project Plan vs Project Management Plan. Retrieved online fromhttps://pmstudycircle.com/2012/01/project-plan-vs-project-management-plan/.

Milyuti, M. A. (2018).Introduction of Building Information Modeling (BIM) Technologies in Construction, Journal of Physics:Conf. Series Retrieved online from doi :10.1088/17426596/1015/4/042038.

Nazib, F. (2010). Construction Industry and Its Characteristics. Retrieved online from https://kumahauing.wordpress.com/2010/11/13/construction-industry-and-itscharacteristics/.

Qian,A. (2012). Benefits and ROI of BIM for Multi-Disciplinary Project Management. National University of Singapore. Retrieved online from http://www.icoste.org/wpcontent/uploads/2011/08/Benefits-and-ROI-of-BIM-for-Multi-Disciplinary-ProjectManagement.pdf. 